\title{
International Journal of Canadian Studies
}

Revue internationale d'études canadiennes

\section{A Canadian Alternative to the "Clash of Civilizations"}

\section{Michael Keren}

Numéro 37, 2008

Canadian Challenges

Les défis canadiens

URI : https://id.erudit.org/iderudit/040794ar

DOI : https://doi.org/10.7202/040794ar

Aller au sommaire du numéro

Éditeur(s)

Conseil international d'études canadiennes

ISSN

1180-3991 (imprimé)

Découvrir la revue

Citer cet article

Keren, M. (2008). A Canadian Alternative to the "Clash of Civilizations". International Journal of Canadian Studies / Revue internationale d'études canadiennes, (37), 41-55. https://doi.org/10.7202/040794ar
Résumé de l'article

Cet article montre comment le roman de Yann Martel, L'histoire de Pi, qui perpétue la tradition canadienne bien établie consistant à combler le fossé culturel, offre une solution de rechange à la théorie du " choc des civilisations " en vogue sur la scène internationale aujourd'hui. Il soutient que le roman réfute trois piliers de la théorie - le fait de mettre le renouveau religieux en contradiction avec la rationalité scientifique, le fait d'utiliser la civilisation pour nier les autres civilisations et l'hypothèse que le conflit entre les civilisations est immanent - et propose une sorte de coexistence entre les civilisations conforme aux normes de la politique étrangère du Canada. 


\title{
A Canadian Alternative to the "Clash of Civilizations"
}

\begin{abstract}
This article shows how Yann Martel's novel Life of $\mathrm{Pi}$, following a wellestablished Canadian tradition of breaching cultural divides, provides an alternative to the "clash of civilizations" theory prevalent in today's international arena. It argues that the novel challenges three foundations of the theory - the consideration of religious revival in contradiction to scientific rationality, the tying of civilization to the negation of other civilizations, and the assumption that conflict between civilizations is immanent - and proposes an alternative of coexistence between civilizations, consistent with Canadian foreign policy norms.
\end{abstract}

\section{Résumé}

Cet article montre comment le roman de Yann Martel, L'histoire de $\mathrm{Pi}$, qui perpétue la tradition canadienne bien établie consistant à combler le fossé culturel, offre une solution de rechange à la théorie $d u$ "choc des civilisations " en vogue sur la scène internationale aujourd'hui. Il soutient que le roman réfute trois piliers de la théorie - le fait de mettre le renouveau religieux en contradiction avec la rationalité scientifique, le fait d'utiliser la civilisation pour nier les autres civilisations et l'hypothèse que le conflit entre les civilisations est immanent - et propose une sorte de coexistence entre les civilisations conforme aux normes de la politique étrangère du Canada.

In 1955, Lester Pearson, then secretary of state for external affairs who two years later won the Nobel Peace Prize, published Democracy in World Politics. In that book, Pearson wrote: "The major issues of diplomacy for several centuries have, for the West, been reflections of the changing relations between the various states of Europe. Today the most far-reaching problems arise no longer between nations within a single civilization but between civilizations themselves" $(1955,82)$.

This observation, that civilizations are replacing nation-states as main actors in the international system, was accompanied by foreign policy conclusions that affected Canadian foreign policy for years to come. Pearson emphasized the renaissance of cultures in Asia. If in the 19th century the Orient gave the impression of stagnation, with its great periods of achievement behind it, a new vitality was now apparent. Pearson 
welcomed that vitality, writing that the new restlessness and vision among Islamic, Indian, and Southeast Asian civilizations "is something which all men of good-will should welcome" $(1955,83)$.

Pearson was aware of the fear created by rising new powers but claimed that the revival of ancient civilizations, however unfamiliar, may be "full of interest to those with the humility and awareness to learn" $($ ibid.). He did not ignore the conflicts and wars between civilizations in the past but argued that they do not prevent an option of coexistence: "We are now emerging into an age when different civilizations will have to learn to live side by side in peaceful interchange, learning from each other, studying each other's history and ideas and art and culture, mutually enriching each other's lives. The alternative, in this overcrowded little world, is misunderstanding, tension, clash, and catastrophe" (83-84).

The need to coexist with other civilizations in order to avoid a clash has become a cornerstone of Canadian foreign policy. The devotion to peacekeeping, the operation of CIDA, Canada's wheat sales to China and the Soviet Union during the Cold War, and its efforts to serve as honest broker in various international crises were largely an outgrowth of a realization that Canada's national survival vis-à-vis friends and foes alike depends on its breach of the worldwide political and cultural divides. Pearson's vision has become part of the Canadian saga, largely because that vision had deep roots. Canadian culture was always marked by an urge to distinguish itself from cultural allies such as Great Britain and the United States while recognizing the rights of aboriginal people and absorbing immigrants under the banner of multiculturalism, which has granted Canada the title of "first postmodern state"(Bumsted 2001,32). It may thus not be incidental that one of the strongest objections to the "clash of civilizations" theory, so prevalent in world politics today, has been provided in a novel by a Canadian author.

This theory has been elaborated by Harvard professor Samuel Huntington in an article in Foreign Affairs in 1993 and three years later in a book titled The Clash of Civilizations and the Remaking of World Order (2003). The book has been declared a work "touched by genius ... a brilliant, riveting, and utterly original book, masterful in presentation and brimming with insight, its disturbing conclusions corroborated by an impressive array of data and well-chosen quotations" (Bacevich 1997, 40). Few books have sparked so much interest and discussion, especially after the attack on the United States on September 11, 2001, when Huntington's insights on international politics as dominated by cultural antagonisms seemed to many to have been confirmed by the events. Huntington argues that in the post-Cold War world, the most important distinctions between people are no longer ideological, political, or economic but cultural. Nations are preoccupied with their cultural identity and use politics to not only advance their interests but also define that identity. 
Huntington defines "civilization" as the highest level of identification to which a person belongs, emphasizing religion as a central defining feature of any civilization. The great religions prevailing in the world, Christianity, Islam, Hinduism, and Confucianism, are central in his design of international politics as dominated by seven civilizations: Sinic, Japanese, Hindu, Islamic, Orthodox, Western, and Latin American. Western civilization, for example, has its origins in "Western Christendom" (2003, 70). Western Christianity, Huntington writes, first Catholicism and then Catholicism and Protestantism, is historically the single most important characteristic of Western civilization, having provided its adherents with a sense of community that distinguished them from Islam, Eastern Orthodoxy, and so on.

Considering the first Gulf War as the primary conflict between civilizations in the modern era, Huntington predicts a sharpening of conflicts in the manner of tribal wars. "Civilizations are the ultimate human tribes," he writes, "and the clash of civilizations is tribal conflict on a global scale" $(2003,207)$. In particular, he points at the clash between the West and Islam, claiming that its causes lie not in transitory phenomena such as $12^{\text {th }}$-century Christian passion or $20^{\text {th }}$-century Muslim fundamentalism but rather "flow from the nature of the two religions and the civilizations based on them" $(2003,210)$.

Critics have related to various aspects of the book. It has been argued that most Western states are now multi or bicultural and are becoming more so. They are thus potentially part of multiple civilizations, a situation Huntington brushes over by designating religion as the deciding factor (Graham 1994). If transnational efforts to impose one culture on another invite strife, it was asked, why should such efforts have harmonious results if attempted within a single nation-state? And is it not still possible for countries to have allies across the civilizational divide? (Elliott 1996). Some have called for public denunciation of the book, claiming that Huntington has made a pitch to the ears of the powerful, a worrisome pitch because of its xenophobic and self-fulfilling prophecy. Its thesis should not guide $21^{\text {st }}$-century policy-making (O'Brien 1997).

One of the strongest criticisms of the "clash of civilizations" theory can be found in Canadian author Yann Martel's novel Life of $P i$, which provides a profound examination of the theory's philosophical foundations and proposes an alternative of coexistence between civilizations, consistent with Pearson's vision. I do not mean to imply that this novel, or for that matter any novel, can be read as a national emblem or that Martel's fiction is representative of Canadian literature. Martel has obviously not intended to provide a Canadian alternative to Huntington, but in many ways he did. For one, following his receipt of the prestigious Booker prize for Life of $P i$ in 2002 , he has been embraced by official Canada. His rejection of religious exclusionism, for instance, has been attributed by an official Foreign 
Affairs document to his being a child of the Quiet Revolution (Foreign Affairs 2003). The Quiet Revolution refers to the social changes taking place in Quebec, Martel's province, under Liberal leader Jean Lesage in the sixties (Bélanger 2000). Martel's extensive visits to mosques, churches, and temples, and his reading of the Bible, the Quran, and the Bhagavad-Gita in preparation for $L$ ife of $P i$ have been attributed to that revolution in which traditional religious, boundaries were partly replaced by concerns with modernization, planning, and social change. In interviews he gave after publication of the novel, Martel himself emphasized his Canadian reference point: "I can't live for more than four years outside of Canada ... I'm Canadian, so ultimately that is my reference point" (Guardian 2002).

The Canadian origins of Martel's thought should not be stretched beyond limit, especially since $L$ ife of $P i$ itself plays down any fixed identities, but it is hard not to see the roots of his message of coexistence between civilizations in legal documents like the constitutional act of 1982, which recognizes the rights of Indian, Inuit, and Métis people; in the Canadian multiculturalism act, which promotes "the understanding that multiculturalism is a fundamental characteristic of the Canadian heritage and identity and that it provides an invaluable resource in the shaping of Canada's future" (Canadian Multiculturalism Act 1985); in political organizations like the National Muslim-Christian Liaison Committee; in practices like the support given by the Canadian-Jewish congress for Sikh army veterans who were prevented from entering the Royal Canadian Legions; or in cultural products like Leonard Cohen's "Sisters of Mercy," to mention only a few examples.

Let us now consider the alternative proposed in Life of $P i$ to the "clash of civilizations" theory. There has been considerable debate over the examination of novels as sources of insights on political affairs (Keren 2003), but here such an examination is particularly tempting because Martel presents the fictional tale of 16-year-old Pi Patel, an Indian boy finding himself with a 450-pound Bengal tiger on a lifeboat in the Pacific Ocean, as a statement about reality: "That's what fiction is about, isn't it, the selective transforming of reality? The twisting of it to bring out its essence?" (Martel 2001, viii). The symbolic nature of Life of P $i$ allows its consideration as a simplified model of the world, of the kind sought by Huntington, who admits that the picture of world politics he draws is highly simplified. Like the tale of a boy and a tiger on a lifeboat, "it omits many things, distorts some things, and obscures others. Yet if we are to think seriously about the world, and act effectively in it, some sort of simplified map of reality, some theory, concept, model, paradigm, is necessary" (Huntington 2003, 29). Thus, it seems useful to derive insights on world politics from a parable that to a large extent provides what Huntington calls "a map that both portrays reality and simplifies reality in a way that best serves our purposes" $(2003,31)$. 
Both works are treated here as simplified models of the world order at the turn of the millennium and are examined for the prescriptions stemming from those models. In what follows, I analyze three foundations of Huntington's "clash of civilizations" theory: the consideration of religious revival in contradiction to scientific rationality, the tying of civilization to the negation of other civilizations, and the assumption that conflict between civilizations is immanent. Analyzing $L i f e$ of $P i$ as a symbolic sea journey tale reminiscent of Robinson Crusoe, Moby Dick, or The Old Man and the $\mathrm{Sea}$, and viewing the relations between the boy and the tiger as a metaphor, I show how each of these foundations is challenged.

\section{Religion and Rationality}

As a scholar of modernization, Huntington is concerned with the processes of industrialization, urbanization, increasing levels of literacy, education and wealth, social mobilization, and diversifying occupational structures. Although he stresses that there is no one pattern of modernization and clearly dissociates modernization from Westernization, he distinguishes between the scientific rationality underlying these processes of modernization and religion. While modernization is a product of the tremendous expansion of scientific and engineering knowledge beginning in the 18th century, religion is a 20th century response to it. "The most obvious, most salient, and most powerful cause of the global religious insurgence," he writes, "is precisely what was supposed to cause the death of religion: the processes of social, economic, and cultural modernization that swept across the world in the second half of the twentieth century" (Huntington 2003, 97).

This view is shared by many who consider the contemporary resurgence of religion as a reaction against the secularism, moral relativism, and self-indulgence of the modern industrial state making use of the impressive achievements in science and engineering of the last two centuries to control and shape its environment. Its success in doing so creates vacuums filled by religious groups. As Huntington puts it, "In times of rapid social change, established identities dissolve, the self must be redefined, and new identities created. For people facing the need to determine Who am I? Where do I belong? religion provides compelling answers, and religious groups provide small social communities to replace those lost through urbanization" $(2003,97)$.

Martel, however, refuses to accept the distinction between a secular, scientific, rational culture associated with modernity and religion. He brings the distinction ad absurdum in the figure of Pi's biology teacher, $\mathrm{Mr}$. Satish Kumar, who believes in science but not in God. Mr. Kumar's total adherence to science is apparent in the shape of his body: "His construction was geometric: he looked like two triangles, a small one and a larger one, balanced on two parallel lines" $(2001,25)$. He is a regular visitor to the zoo 
managed by Pi's father, where each animal represents the triumph of logic and mechanics. To him, nature is an exceptionally fine illustration of science: "When Mr. Kumar visited the zoo, it was to take the pulse of the universe, and his stethoscopic mind always confirmed to him that everything was in order, that everything was order. He left the zoo feeling scientifically refreshed" (26).

As a young man, Mr. Kumar was racked with polio and it was not God who saved him but medicine, which turned him into an atheist. $\mathrm{Pi}$ is influenced by him and begins to study zoology but also realizes that scientific knowledge without religious belief is meaningless. Once disaster .strikes - the Japanese ship on which the Patels and their zoo animals are sailing to Canada sinks and his whole family dies - reason alone does not provide answers. "And what of my extended family - birds, beasts and reptiles?" asks the boy who has lost everything: "They too have drowned. Every single thing I value in life has been destroyed. And I am allowed no explanation? I am to suffer hell without any account from heaven? In that case, what is the purpose of reason ... Is it no more than to shine at practicalities - the getting of food, clothing and shelter? Why can't reason give greater answers?" (98).

Reason cannot give the answers and yet $\mathrm{Pi}$ does not give it up. The nover is in many ways a song of praise to reason that is not devoid of a belief in God, and to a belief in God that does not exclude reason. At no point, for instance, does Pi rely on external redemption: "I had to stop hoping so much that a ship would rescue me. I should not count on outside help. Survival had to start with me. In my experience, a castaway's worst mistake is to hope too much and do too little. Survival starts by paying attention to what is close at hand and immediate. To look out with idle hope is tantamount to dreaming one's life away" (169). Moreover, Pi's belief in God is not blind: "Faith in God is an opening up; a letting go, a deep trust, a free act of love - but sometimes it was so hard to love" (208). Most importantly, it does not promise survival: "God's hat was always unraveling. God's pants were falling apart. God's cat was a constant danger. God's ark is a jail. God's wide acres were slowly killing me. God's ear didn't seem to be listening"(209).

But reason does also not assure survival unless accompanied by religious faith: "I was giving up. I would have given up - if a voice hadn't made itself heard in my heart. The voice said, 'I will not die. I refuse it. I will make it through this nightmare. I will beat the odds, as great as they are"'(148). Once he hears the voice, Pi begins to accumulate every piece of scientific knowledge in the fields of zoology, physics, engineering, and so on in order to survive. For example, "You see, waves and steady winds are usually perpendicular to each other. So, if a boat is pushed by a wind but held back by a sea anchor, it will turn until it offers the least resistance to the wind that is, until it is in line with it and at right angle to the waves, which makes for a front-to-back pitching that is much more comfortable than a 
side-to-side rolling ... What may seem like a detail to you was something which would save my life" (170).

Martel realizes the difficulty in accepting the combination he proposes between rational, knowledge-based action and religious belief. This difficulty is nicely demonstrated toward the end of the novel when the miraculous survival story is put to the test of reason. Two Japanese officials investigating the sinking of the ship listen to Pi's story in disbelief because they apply rational criteria to it, but Martel shows these criteria are insufficient. Let me conclude this section by quoting from the exchange developing when the two rational officials say they do not believe that a 16-year-old boy could survive a journey on a lifeboat with a 450-pound Bengal tiger:

"'In a lifeboat? Come on, Mr. Patel, it's just too hard to believe!' 'Hard to believe? What do you know about hard to believe? ... Love is hard to believe, ask any lover. Life is hard to believe, ask any scientist. God is hard to believe, ask any believer. What is your problem with hard to believe?' 'We're just being reasonable,' 'So am I! I applied my reason at every moment. Reason is excellent for getting food, clothing and shelter. Reason is the very best tool kit. Nothing beats reason for keeping tigers away. But be excessively reasonable and you risk throwing out the universe with the bathwater"'(297-98).

\section{Civilization as Negation}

Huntington's conception of civilization is strongly related to the negation of other civilizations, and much of his book is devoted to advancing the notion that civilizations are mutually exclusive. Considering the adherence to cultural heritage as a human need in the post-Cold War era, he writes that peoples and nations develop their identity by adhering to the things that mean most to them, which are determined in relation to others: "People use politics not just to advance their interests but also to define their identity. We know who we are only when we know who we are not and often only when we know whom we are against" $(2003,21)$.

Huntington believes that there can be no true friends without true enemies and that unless we hate what we are not, we cannot love what we are. "For peoples seeking identity and reinventing ethnicity," he writes, "enemies are essential and the potentially most dangerous enemies occur across the fault lines between the world's major civilizations" $(2003,20)$. The very definition of civilization in this book involves negation: "Civilizations are the biggest 'we' within which we feel culturally at home as distinguished from all the other 'them' out there" $(2003,43)$.

In support of the notion that civilizations are mutually exclusive and depend on each other's negation, Huntington makes use of social 
psychology theories like "distinctiveness theory," claiming that people define themselves by what makes them different from others in a particular context. Citing findings in social psychology showing, for example, that a woman psychologist in the company of a dozen women who work at other occupations thinks of herself as a psychologist while in a company of a dozen male psychologists she thinks of herself as a woman, Huntington concludes that "people define their identity by what they are not" (2003, 67). This conclusion is reinforced by a view of religion - a central component of any civilization - as "positing a basic distinction between believers and nonbelievers, between a superior in-group and a different and inferior out-group" $(2003,97)$.

The fictional character of 16-year-old $\mathrm{Pi}$ is used by Martel to challenge the notion of mutual exclusiveness of cultures. The author proposes an alternative notion of syncretism - that is, the adaptation and melding of different religious traditions. His starting point resembles Huntington's claim that there exists no universal religion or civilization and that it would be naïve to expect the coming together of humans throughout the world accepting common values, beliefs, orientations, practices, and institutions. As Huntington puts it, the sharing of a few fundamental values and institutions throughout history may explain some constants in human behaviour but does not illuminate or explain history.

Martel agrees that an exploration of contemporary culture cannot focus on what Huntington calls "the Davos culture" $(2003,57)$ - that is, the small percentage of people in the world who are fluent in English, travel a lot, control international institutions and business enterprises, and share values of individualism, market economy, and political democracy. Life of $P i$ is rooted in industrialized India and the Patel family is to a large extent part of the Davos culture: "We're a modern Indian family; we live in a modern way; India is on the cusp of becoming a truly modern and advanced nation" $(2001,74)$. Consider the description of Pi's father, the zoo manager: "Father saw himself as part of the New India - rich, modern and as secular as ice cream. He didn't have a religious bone in his body. He was a businessman, pronounced businessman in this case, a hardworking, earthbound professional, more concerned with inbreeding among the lions than any overarching moral or existential scheme" (65).

Martel realizes that this form of existence often leads to a search for a more profound identity but does not presume mutual exclusiveness of religions. His protagonist constructs a religion based on incorporation rather than negation. When we first encounter $\mathrm{Pi}$ as an old man telling his story to the author, his house resembles a temple for all three religions Hinduism, Christianity, and Islam, "Upstairs in his office there is a brass Ganesha sitting cross-legged next to the computer, a wooden Christ on the Cross from Brazil on a wall, and a green prayer rug in a corner" (46). As we follow Pi's encounter with the three religions, we are faced with the 
possibility that a cultural identity can be constructed that is based on incorporation of elements from all religions.

Pi was born a Hindu. "I owe to Hinduism the original landscape of my religious imagination, those towns and rivers, battlefields and forests, holy mountains and deep seas where gods, saints, villains and ordinary people rub shoulders, and, in doing so, define who and why we are" (50). The rubbing of shoulders, however, does not imply separation of one religious group from others but rather allows a confident look outward, toward other religions. By listening to Lord Krishna, Pi is led to meet Jesus Christ. This is not the meeting advocated by Christian evangelicals. Martel objects to evangelicals of all religions: "But we should not cling! A plague upon fundamentalists and literalists!" (49). Nor is it a simple revelation. To a young Hindu, Christian theology seems bizarre: "What? Humanity sins but it's God's son who pays the price?" (53). He can understand a god who puts up with adversity; after all, the gods of Hinduism also face their fair share of thieves, bullies, kidnappers, and usurpers, but the element of humiliation in Christianity is beyond his grasp: "I couldn't imagine Lord Krishna consenting to be stripped naked, whipped, mocked, dragged through the streets and, to top it off, crucified-and at the hands of mere humans, to boot" (54).

Christianity is too hurried for the Hindu boy: "IfHinduism flows placidly like the Ganges, then Christianity bustles like Toronto at rush hour" (57). And yet it appeals to him because of its temporality: "Christianity stretches back through the ages, but in essence it exists only at one time: right now" (57). Since Pi lives "right now," he becomes a Christian, as well as a Muslim. Islam, he says, has a reputation even worse than other religions: "fewer gods, greater violence" (58), but it provides him with an element lacking in other religions: the immediacy of contact with God: "It felt good to bring my forehead to the ground. Immediately it felt like a deeply religious contact" (61).

Martel is aware of the tendency of organized religions to consider their ceremonies and rituals as mutually exclusive, but to him this is neither a necessary not a deterministic trend. The dialogue he constructs between Pi's father and three wise men belonging to the three organized religions Hinduism, Christianity, and Islam - may be read as an ironic statement on the assumption that the clash of civilizations is inevitable: "What is your son doing going to temple?' asked the priest. 'Your son was seen in church crossing himself,' said the imam. 'Your son has gone Muslim,' said the pandit" (64). This kind of talk seems anachronistic in comparison to Pi's new identity (shared, it seems, by many early 21 st-century individuals) that crosscuts organized religions and cultures. As only Pi's mother seems to understand by nature of her being mum, bored and neutral on the subject of religion and hence a sharp observer of the contemporary world, the boy is "marching to a different drumbeat of progress" (75). He is certainly 
marching to a different drumbeat than the three wise men marching toward a clash of civilizations.

Martel makes explicit what he understands Pi's consciousness to consist of: "moral exaltation; lasting feelings of elevation, elation, joy; a quickening of the moral sense, which strikes one as more important than an intellectual understanding of things; an alignment of the universe along moral lines, not intellectual ones" (63). The author realizes that in a world believing either in scientific rationality or in fundamentalism and literalism, both of which lack a vision for life, it may be hard to develop such a moral attitude, but he believes that human consciousness marked by "a trusting sense of presence and of ultimate purpose" (ibid.) may be developing because, as in the case of $\mathrm{Pi}$, neither science nor organized religion provides us with answers in the face of disaster.

\section{The Immanence of Conflict}

Huntington leaves little doubt that the mapping of world politics along the lines of civilizations implies an immanent conflict, which can be expected to be bloodier than the conflict between states. Wars between clans, tribes, ethnic groups, religious communities, and nations, he writes, have been prevalent in every era because they are rooted in the identities of people. They tend to be vicious and bloody, since fundamental issues of identity are at stake. Conflicts of identity can be expected to involve massacres, terrorism, rape, and torture and are particularly hard to resolve through negotiations and compromise.

Although he realizes the existence of many forms of conflict - cold peace, cold war, trade war, quasi-war, uneasy peace, troubled relations, intense rivalry, competitive coexistence, arms races, and the like Huntington sees little chance to avoid gigantic wars between states of different civilizations, and he even coins a special term, "fault line wars," to describe them. "Fault line wars go through processes of intensification, expansion, containment, interruption, and, rarely, resolution. These processes usually begin sequentially, but they also often overlap and may be repeated. Once started, fault line wars, like other communal conflicts, tend to take a life of their own and to develop in an action-reaction pattern" $(2003,266)$.

Huntington sees the emergence of a "hate dynamics" $(2003 ; 266)$ in which mutual fears, distrust, and hatred feed on each other. "Each side dramatizes and magnifies the distinction between the forces of virtue and the forces of evil and eventually attempts to transform this distinction into the ultimate distinction between the quick and the dead" (ibid.). In his description of the dynamics of these wars, religion is given a central role: "In the course of the war, multiple identities fade and the identity most meaningful in relation to the conflict comes to dominate. That identity 
almost always is defined by religion. Psychologically, religion provides the most reassuring and supportive justification for struggle against 'godless' forces which are seen as threatening" $(2003,267)$.

"As the fault line war intensifies," Huntington adds, "each side demonizes its opponents, often portraying them as subhuman, and thereby legitimates killing them" $(2003,271)$. These words sound so accurate that it is hard to imagine an intellectual construct contradicting them, and yet such a construct is worth considering if only to avoid the turning of Huntington's assumptions, widely accepted by policy-makers and large parts of the public, into a self-fulfilling prophecy. Martel raises the option of coexistence between the fiercest enemies nature has produced, but most interestingly presents it not as a form of idealism but as a realistic strategic option and policy program.

At no point in Martel's novel is there a shred of delusion that Bengal tigers are not dangerous enemies and would not remain so under all circumstances. As a child, Pi learned about the wild nature of animals: "I quite deliberately dressed wild animals in the tame costumes of my imagination. But I never deluded myself as to the real nature of my playmates" $(2001,34)$. When the boy finds himself on a lifeboat with the tiger named Richard Parker, the fear of the animal's wild nature is not lessened just because the two share the same fate: "He was a fierce, 450-pound carnivore. Each of his claws was as sharp as a knife ... Any second I expected to see Richard Parker rising up and coming for me" (108).

Martel does not expect harmony on the lifeboat, and any illusions the reader may have for a Disney-like tale are shattered by a gruesome description of the way various animals present in the beginning on the lifeboat are killed one by one: "A massive paw landed on its shoulders. Richard Parker's jaws closed on the side of the hyena's neck. Its glazed eye widened. There was a noise of organic crunching as windpipe and spinal cord were crushed. The hyena shook. Its eyes were dull. It was over" (151). Slowly and gradually, Martel leads us to the point at which the harsh reality cannot be overlooked: "Now we were two. In five days the populations of orang-utans, zebras, hyenas, rats, flies and cockroaches had been wiped out. Except for the bacteria and worms that might still be alone in the remains of the animals, there was no other life on the lifeboat but Richard Parker and me" (171).

Not only is the existential state of affairs clear, so is the lack of good options to cope with it. Like a state - or civilization - finding itself vis-à-vis a fierce and dangerous enemy, all the options predicted by Huntington to be taken under these conditions - massacres, terrorism, rape, torture - are considered but are also found lacking. The parable may be seen as a demonstration of the futility of a whole range of options floating in the international sphere today. Here is Pi calculating his options: 
"Plan Number one: Push Him off the Lifeboat. What good would that do? Even if I manage to shove 450 pounds of living, fierce animal off the lifeboat, tigers are accomplished swimmers ... Plan Number Two: Kill Him with the Six Morphine Syringes. But I had no idea what effect they would have on him. Would they be enough to kill him? ... Plan Number Three: Attack Him with All Available Weaponry. Ludicrous. I wasn't Tarzan ... Plan Number Four: Choke Him ... A clever, suicidal plan. Plan Number Five: Poison Him, Set Him on Fire, Electrocute Him. How? With what? Plan Number Six: Wage a War of Attrition..." (157-58).

This list of strategies aimed to overcome the tiger by force exposes a common fallacy that military plans are more "realistic" than a search for coexistence. Pushing, killing, and attacking one's enemy with all available weaponry is often mistaken for realpolitik, but not by Martel who considers all the above options, including the option of attrition, as an outgrowth of fear, life's only true opponent. Fear leads one to make rash decisions. "You dismiss your last allies, hope and trust. There, you've defeated yourself. Fear, which is but an impression, has triumphed over you" (162).

Once the 16-year-old boy gives up the futile military plans (whose futility seems to grow proportionately to the degree of fear), he begins to make practical use of the unique combination of reason and faith he is endowed with. He assesses that in order to survive, a training program must be devised for the tiger that would delimit the territory between them and make Pi's territory utterly forbidden for Richard Parker. The interesting point about this training program, described at length in the novel, is its reliance on the continuing presence of the tiger in the boat. "It was not a question of him or me, but of him and me. We were, literally and figuratively, in the same boat. We would live - or we would die together" (164). Pi gets inspiration, strength, and will to live from Richard Parker. It is the irony of the story, writes Martel, that the tiger's presence brought peace, purpose, and even wholeness to the boy.

This point should be stressed. The immanence of war between civilizations implies that any civilization would feel more comfortable were it left alone in the universe. However, Martel reminds us that multiculturalism, a concept Huntington dismisses, may not just be a comfortable political solution (or slogan) when incumbents of different cultures are forced to live side by side; it also has intrinsic value: "I will tell you a secret: a part of me was glad about Richard Parker. A part of me did not want Richard Parker to die at all, because if he died I would be left alone with despair, a foe even more formidable than a tiger. If I still had the will to live, it was thanks to Richard Parker. He kept me from thinking too much about my family and my tragic circumstances. He pushed me to go on living. I hated him for it, yet at the same time I was grateful" (164). 
Martel's belief in coexistence between civilizations stems from his insight that war is nobody's desirable alternative if it can be avoided. This is sometimes hard to believe in light of the swiftness in which minor incidents spark major wars between nations, but it may be at least partly true in the human sphere as it is in the animal kingdom: "If I survived my apprenticeship as a high seas animal trainer, it was because Richard Parker did not really want to attack me. Tigers, indeed all animals, do not favor violence as a means of settling scores" (206). At the same time, Martel understands that the line between coexistence and being killed is very thin. As he advises any animal trainer: "You must be careful. You want to provoke your animal, but only so much. You don't want it to attack you outright. If it does, God be with you. You will be torn to pieces, trampled flat, disemboweled, very likely eaten" (203).

\section{Conclusion}

As hard as it is to derive insights on world politics from fictional tales whose interpretation is always uncertain, the symbolism we find in Life of Pi sparks fresh ideas that challenge the "clash of civilization" theory and provide a different set of policy prescriptions than the theory implies. Huntington is not explicit on what the world ought to do in light of the transformation it undergoes from economic, political, and ideological wars to fault line wars, but from the examples he uses it becomes clear that the mapping of the world along cultural lines means that people of similar cultures ought to stick together and not develop illusions about long-lasting coalitions crossing the cultural divide.

In his discussion of the relations between Russia and Ukraine, for instance, he claims that since the cultural divide crosses not between these two states but between Orthodox Eastern Ukraine and Uniate Western Ukraine, the state-oriented approach that predicts conflict between the two states, and therefore urges Ukraine to develop nuclear capability if it is to stand up to Russia, should be replaced by a different policy:

A civilizational approach would encourage cooperation between Russia and Ukraine, urge Ukraine to give up its nuclear weapons, promote substantial economic assistance and other measures to help maintain Ukrainian unity and independence, and sponsor contingency planning for the possible breakup of Ukraine (2003, 37).

In other words, peoples and nations ought to define their allies in cultural terms. Europe and America in particular, being the backbone of Western civilization, ought to align. This prescription adheres to the common sense of many, but Martel's challenge is worth considering. The analysis of Life of $P i$ as a symbolic tale, and of the relations between the boy and the tiger as a metaphor, makes one conclude that much more effort ought to be devoted to coexistence across the cultural divide. By constructing a metaphor of 
coexistence, Martel does not exclude the possibility of a clash. He also does not promise us that in conditions of coexistence, utopia will prevail. To the contrary, he draws a rather gloomy picture of human existence: "Life on a lifeboat isn't much of a life. It is like an end game in chess, a game with few pieces. The elements couldn't be more simple, nor the stakes higher. Physically it is extraordinarily arduous, and morally it is killing. You must make adjustments if you want to survive" (217).

One of the adjustments, however, is giving up the fascination with the "clash of civilizations" theory. Unlike Huntington, Martel does not allow us to rub shoulders and indulge in the justice of the Western cause. Rather, he makes us realize that in order to cope with the harsh political realities we face, we need to reach out to other cultures and religions; for the knowledge, love, hope, and a sense of purpose required to survive the hard journey into the 21 st century may be found outside our own civilization.

This is advocated as a realistic approach to human affairs, which brings up once again Lester Pearson's claim that coexistence is a realistic policy. As Pearson $(1955,121)$ writes in Democracy and World Affairs, "The true realist is the man who sees things both as they are and as they can be. In every situation there is the possibility of improvement, in every life the hidden capacity for something better. True realism involves a dual vision, sight and insight. To see only half the situation, either the actual or the possible, is to be not a realist but in blinkers.

\section{Note}

* I am indebted to Myron J. Aronoff of Rutgers University and Karim-Aly Kassam of Cornell University for their helpful comments on a former draft of this article.

\section{References}

Bacevich, Andrew J. 1997. "The Clash of Civilizations and the Remaking of World Order." First Things 73 (May): 40-45.

Bélanger, Claude. 2000. "The Quiet Revolution." In Quebec History, http://www2.marianopolis.edu/quebechistory/events/quiet.htm.

Bumsted, Jack. 2001. "Visions of Canada: A Brief History of Writing on the Canadian Character and the Canadian Identity." In $A$ Passion for Identity. Ed. David Taras and Beverly Rasporich, 17-35. Scarborough, ON: Nelson.

Canadian Multiculturalism Act. 1985. Department of Justice Canada, http://laws.justice.gc.ca/en/c-18.7.

Elliott, Michael. 1996. "When Cultures Collide." Washingtonpost.com. 1 December.

Foreign Affairs and International Trade Canada. 2003. "Yann Martel's Success," http://www.dfait-maeci.gc.ca/arts/ss_yann-en.asp.

Graham, James. 1994. "Samuel Huntington's Clash of Civilizations," http://www.historyorb.com.

Guardian. 2002. "Third Time Lucky: Portrait." 23 October, http://books.guardian.co.uk/bookerprize2002/story/0,817341,00.html.

Huntington, Samuel. 2003. The Clash of Civilizations and the Remaking of World Order. New York: Simon and Schuster.

Keren, Michael. 2003. The Citizen's Voice: Twentieth Century Politics and Literature. Calgary: Calgary University Press. 
Martel, Yann. 2001. Life of Pi. Orlando: Harcourt.

O'Brien, Robin. 1997. "The Clash of Civilizations and the Remaking of World Order." SAIS Review 17 (2): 208-10.

- Pearson, Lester. 1955. Democracy in World Politic. Toronto: S.J. Reginald Saunders. 